\title{
Pengaruh Transparancy, Accountability, Responsibility, Independency, dan Fairness Pada Kinerja Keuangan Lembaga Perkreditan Desa
}

\author{
Made Oka Candra Andreana ${ }^{1}$ \\ I Gde Ary Wirajaya ${ }^{2}$
}

\author{
${ }^{1}$ Fakultas Ekonomi dan Bisnis Universitas Udayana (Unud), Bali, Indonesia \\ email: madeokacandraandreana @ gmail.com /Telp: +62 81236054001 \\ ${ }^{2}$ Fakultas Ekonomi dan Bisnis Universitas Udayana (Unud), Bali, Indonesia
}

\begin{abstract}
ABSTRAK
Lembaga Perkreditan Desa (LPD) harus melaksanakan tata kelolanya dengan baik untuk dapat mencapai tujuan yang diharapkan. Salah satu hal yang dapat dilaksanakan untuk tercapainya tata kelola LPD yang baik adalah diterapkannya Good Corporate Governance (GCG). Prinsip transparancy, accountability, responsibility, independency, dan fairness merupakan kelima prinsip dari GCG tentang bagaimana mengelola suatu organisasi bisnis dengan baik. Populasi penelitian adalah 107 LPD dan 55 LPD sebagai sampel. Setiap LPD diambil 2 responden sehingga jumlah responden sebanyak 110 responden. Metode penentuan sampel menggunakan purposive sampling. Teknik analisis data yaitu analisis regresi berganda. Berdasarkan hasil pengujian hipotesis didapatkan hasil bahwa prinsip $G C G$ berpengaruh positif terhadap kinerja keuangan LPD di Kabupaten Klungkung.

Kata Kunci: Good corporate governance, lembaga perkreditan desa, kinerja keuangan, return on assets
\end{abstract}

\begin{abstract}
Lembaga Perkreditan Desa (LPD) has to run its management well to achieve the expected goals. One thing that can be done to achieve a good LPD management is the implementation of Good Corporate Governance (GCG). The principle of transparancy, accountability, responsibility, independency, and fairness are the five principles of GCG on how to manage a business organization well. The sample population was 107 LPD, and 55 LPD was used as the sample. 2 respondents were taken from each LPD, therefore the number of the respondents is 110. The method used in determining the sample was purposive sampling. The technique of analyzing the data was analysis of multiple regression. Based on the result of hypothesis analysis, it was found that the principles of GCG have a positive effect on the financial performances of LPD in the Klungkung regency.
\end{abstract}

Keywords: Good corporate governance, lembaga perkreditan desa, financial perfomances, return on assets

\section{PENDAHULUAN}

Di Indonesia terdapat organisasi bisnis yang berbentuk sumber pendanaan masyarakat khususnya di Bali terdapat lembaga keuangan yang berdiri di setiap desa yang pengelolaannya dikelola oleh desa pakraman yang disebut Lembaga Perkreditan Desa (LPD). Lembaga Perkreditan Desa (LPD) merupakan lembaga keuangan yang memberikan manfaat sosial, ekonomi, dan budaya yang dimiliki 
oleh desa pakraman. Pendirian sebuah LPD di setiap desa adat memiliki tujuan berdasarkan penjelasan peraturan daerah No.2/1998 dan No.8 Tahun 2002 tentang Lembaga Perkreditan Desa (LPD) ialah membantu pembangunan ekonomi di desa pakraman dengan meningkatkan kebiasaan menabung masyarakat desa dan menyediakan kredit dipeuntukkan bagi usaha berskala kecil. Terdapat beberapa permasalahan yang saat ini sedang mengancam LPD di Bali yaitu kualitas dan efektivitas tata kelola pada kebanyakan LPD cukup mengkhawatirkan serta pengaturan dan pengawasan LPD kurang efektif hal tersebut dibuktikan dari banyaknya permasalaahan yang dialami oleh LPD (posbali.id). Dari total 1.433 LPD di Bali tidak semuanya dapat berkembang dengan baik. Hal tersebut memberikan pengaruh pada kinerja dari LPD.

Kinerja merupakan keadaan secara menyeluruh mengenai suatu entitas selama kurun waktu tertentu yang merupakan sebuah pencapaian sebuah hasil yang bersumber dari kegiatan operasional perusahaan yang memanfaatkan sumber daya yang dimiliki. Kinerja keuangan dapat menggambarkan kinerja fundamental perusahaan. Kinerja keuangan dapat diukur dengan menggunakan data fundamental perusahaan dimana data tersebut bersumber dari laporan keuangan perusahaan. Untuk dapat mengatasi permasalahan internal dan eksternal dalam perusahaan yang berkaitan dengan kinerja, pada tahun 2006 Komite Nasional Kebijakan Governance (KNKG) menerbitkan sebuah pedoman untuk pelaksanaan Good Corporate Governance (GCG) yang memiliki tujuan untuk mendukung entitas agar membuat sebuah sistem tata kelola perusahaan yang sehat. 
Good Corporate Governance merupakan ilmu mengenai bagaimana cara perusahaan mengelola perusahaannya dengan baik. Menurut Forum of Corporate Governance on Indonesia tentang Corporate Governance merupakan peraturan peraturan yang mengatur mengenai hubungan antara pemegang saham, pengurus perusahaan, pihak kreditur, pemerintah, karyawan, serta para pemegang kepentingan intern dan ekstern lainnya yang berkaitan dengan hak - hak dan kewajiban mereka (Putri dan Ulupui, 2017). Penerapan GCG diharapkan bisa memberikan manfaat dalam meningkatkan kemampuan operasional perusahaan, meningkatkan kualitas pelayanan kepada para stakeholder, serta proses pengambilan keputusan yang lebih baik dapat memberi dampak terhadap meningkatnya kinerja perusahaan. Good Corporate Governance mendorong perusahaan untuk meningkatkan nilai perusahaan serta akuntabilitas dan sistem pengendalian kegiatan usaha bisnis (Aldridge dan Sutojo, 2008:3-4). Menurut KNKG terdapat lima prinsip Good Corporate Governance antara lain Transparancy, accountability, responsibility, independency, dan fairness. Penerapan prinsip - prinsip GCG tersebut dalam sebuah perusahaan diharapkan dapat menghasilkan keputusan yang lebih baik (KNKG, 2006:5). Apabila tata kelola dalam sebuah entitas itu baik, maka dapat dibuktikan bahwa kecenderungan tanggung jawab perusahaan yang lebih besar (Rambo, 2013).

Suatu organisasi bisnis wajib menerapkan asas Good Corporate Governance $(G C G)$ di segala aspek bisnis karena hal ini dibutuhkan guna menciptakan pasar yang efisien, transparan, dan konsisten dengan peraturan perundang - undangan (KNKG, 2006). Kualitas tata kelola organisasi bisnis 
adalah keadaan yang dibutuhkan guna memberi jaminan dan meningkatkan kepercayaan pemangku kepentingan (Fathi, 2013). Pada suatu organisasi bisnis, prinsip Good Corporate Governance $(G C G)$ diperlukan untuk tercapainya suatu kesinambungan usaha dengan cara memperhatikan para stakeholder (KNKG, 2006). Agency theory diberlakukan dalam organisasi bisnis yang bersifat mencari laba maupun nirlaba selama ada penyerahan mandat pengelolaan tugas kepada pihak lain maka tersebut, pada penelitian ini pihak pengelola Lembaga Perkreditan Desa (LPD) merupakan penerima mandat dari Desa Pakraman.

GCG mempunyai peranan yang amat penting untuk meminimalisir terjadinya konflik yang ada antara pihak pengelola LPD yang berperan sebagai agen dengan pihak pemilik yaitu desa pakraman yang berperan sebagai prinsipal yang dikenal dengan konflik keagenan. Corporate governance merupakan mekanisme pengendalian intern organisasi bisnis untuk mengurangi asimetri informasi antara agen dan prinsipal (Clemente dan Labat, 2009).

Penelitian ini dilakukan atas dasar dimana terdapat permasalahan permasalahan LPD yang ada di Bali dan hasil penelitian terdahulu yang tidak konsisten antara pengaruh prinsip - prinsip GCG dengan kinerja perusahaan. Penelitian Sandraningsih dan Putri (2015) memperoleh hasil bahwa prinsipprinsip GCG memiliki pengaruh positif terhadap kinerja keuangan LPD di Kecamatan Abiansemal Kabupaten Badung. Hal tersebut juga senada dengan penelitian yang dilakukan oleh Dewi dan Putri (2014) yang mendapatkan hasil bahwa prinsip - prinsip GCG berpengaruh positif terhadap kinerja keuangan LPD di Kabupaten Gianyar (Dewi dan Putri, 2014). Namun terdapat penelitian dengan 
hasil yang berbeda yang dilakukan oleh Sastra yang mendapatkan hasil bahwa hanya prinsip transparancy dan accountability yang berpengaruh positif pada kinerja keuangan. Namun prinsip responsibility, independency, dan fairness tidak berpengaruh pada kinerja keuangan LPD (Sastra dan Erawati, 2017). Mahaendrayasa juga mendapatkan hasil yang serupa yang menyatakan bahwa hanya prinsip accountability, independency, dan fairness yang berpengaruh positif terhadap kinerja keuangan LPD. Tetapi prinsip transparancy dan responsibility tidak memiliki pengaruh positif terhadap kinerja keuangan LPD (Mahaendrayasa dan Putri, 2017).

Penelitian ini dilakukan di Kabupaten Klungkung karena Bupati Klungkung memiliki rencana untuk meningkatkan kinerja dari LPD yang ada di Kabupaten Klungkung. Bupati Klungkung ikut serta dalam penyertaan modal LPD yang ada di Kabupaten Klungkung guna memperkuat struktur permodalan LPD, membuka peluang LPD untuk membuat usahanya berkembang, dan membuat peluang menjadi lebih luas bagi masyarakat untuk mendapatkan pelayanan dari LPD sehingga dapat memberikan dampak yang positif terhadap pertumbuhan ekonomi di desa pakraman (klungkungkab.go.id). Permasalahan-permasalahan LPD di Bali serta dukungan Bupati Klungkung atas bantuan penyertaan modal diharapkan dapat untuk mendukung penelitian ini yaitu untuk mengetahui tentang bagaimana pengelolaan LPD di Kabupaten Klungkung yang diukur dengan kinerja keuangannya serta apakah kinerja keuangan tersebut dipengaruhi oleh prinsip transparancy, accountability, responsibility, independency, dan fairness. Penelitian ini memiliki tujuan untuk memperoleh bukti empiris dari pengaruh 
transparancy, accountability, responsibility, independency, dan fairness pada kinerja keuangan LPD di Kabupaten Klungkung serta memberi bukti empiris bahwa teori keagenan yang digunakan dalam penelitian ini dapat menjawab permasalahan yang ada dalam penelitian ini. Hasil dari penelitian ini juga diharapkan dapat bermanfaat untuk memberi kontribusi tambahan ilmu pengetahuan dan pemahaman pada peneliti selanjutnya yang melakukan penelitian dengan topik pengaruh dari prinsip transparancy, accountability, responsibility, independency, dan fairness terhadap kinerja keuangan LPD di Kabupaten Klungkung.

Selain itu, penelitian ini juga dapat dipergunakan sebagai suatu perbandingan dan penyempurnaan pada penelitian-penelitian yang sudah dilakukan sebelumnya. Selain itu, penelitian ini diharapkan dapat dipergunakan sebagai bahan pertimbangan oleh pengelola LPD supaya dalam pengelolaannya mempergunakan prinsip transparancy, accountability, responsibility, independency, dan fairness sebagai pedoman dalam mengelola LPD untuk dapat meningkatkan kinerja keuangan LPD.

Agency Theory adalah sebuah teori yang menjelaskan bahwa terdapat hubungan antara pihak pemilik dan pengelola organisasi bisnis. Pencapaian suatu tujuan dan kinerja organisasi bisnis memiliki kaitan erat dengan kinerja manajemen organisasi (Eisenhardt, 1989). Penerapan Agency Theory pada LPD dapat dilihat pada hubungan antara pihak pengelola LPD dengan Desa Pakraman. Dimana pihak pengelola LPD adalah agen sedangkan Desa Pakraman adalah prinsipal. Pihak pengelola LPD merupakan pihak yang paling banyak mengetahui 
informasi dibandingkan Desa Pakraman dan hal inilah yang menimbulkan asimetri informasi. Asimetri informasi adalah ketidaksetaraan informasi yang dimiliki antara pihak agen dan prinsipal, hal ini dikarenakan pihak agen yaitu pengelola LPD lebih banyak mengetahui informasi dibandingkan dengan pihak prinsipal yaitu desa pakraman.

Untuk meminimalisasi terjadinya asimetri informasi maka diperlukannya kelima prinsip GCG untuk mengatasi permasalahan tersebut yaitu Transparancy, Accountability, Responsibility, Independency, dan Fairness. Transparancy adalah prinsip yang memberikan suatu akses atau kebebasan bagi setiap orang untuk memperoleh informasi tentang pertanggungjawaban perusahaan terhadap pihak yang berkepentingan. Untuk menjaga obyektifitas dalam menjalankan bisnis, perusahaan harus menyediakan informasi yang material dan relevan dengan cara yang mudah diakses dan dipahami oleh pemangku kepentingan (Putri dan Ulupui, 2017:33). Berdasarkan penelitian yang dilakukan oleh Sandraningsih dan Putri (2015), transparancy berpengaruh terhadap kinerja keuangan LPD di Kecamatan Abiansemal Kabupaten Badung. Hal tersebut juga terjadi pada penelitian Bulandari dan Damayanthi (2014) yang mendapatkan hasil bahwa transparancy memiliki pengaruh terhadap kinerja keuangan LPD di Kabupaten Badung. Keterbukaan informasi dalam LPD terhadap pihak yang berkepentingan akan menambah kepercayaan stakeholder dengan LPD tersebut sehingga dapat meningkat kinerja keuangan LPD. Sesuai dengan agency theory, hal ini menunjukkan bahwa semakin transparan LPD dalam mengungkapkan informasi mengenai keadaan LPD menyebabkan peningkatan kepercayaan prinsipal, maka 
kinerja keuangan LPD tersebut akan meningkat pula. Berdasarkan uraian tersebut maka rumusan hipotesis pertama dalam penelitian ini adalah.

$\mathrm{H}_{1}$ : Prinsip transparancy berpengaruh positif pada kinerja keuangan LPD di Kabupaten Klungkung.

Accountability adalah kejelasan dari fungsi, struktur, sistem, pelaksanaan, dan pertanggung jawaban sehingga perusahaan dapat dikelola secara efektif . Oleh sebab itu perusahaan mesti dikelola secara benar, terukur, serta sesuai dengan kepentingan perusahaan dengan tetap mempertimbangkan kepentingan dari stakeholder (Putri dan Ulupui, 2017:36). Berdasarkan penelitian yang dilakukan oleh Dewi dan Putri (2014), prinsip accountability memiliki pengaruh positif pada kinerja keuangan LPD Kabupaten Gianyar. Hal tersebut juga sejalan dengan hasil penelitian yang dilakukan oleh Sastra dan Erawati (2017) yang mendapat hasil bahwa prinsip accountability berpengaruh positif signifikan pada kinerja keuangan LPD. Kejelasan struktur, fungsi, serta wewenang dalam LPD akan membuat pengelolaan LPD berjalan secara efektif serta berdampak pada meningkatnya kinerja keuangan LPD.

Sesuai dengan agency theory, hal ini menunjukkan bahwa semakin jelas wewenang dan fungsi pelaksanaan serta pertanggungjawaban struktur organisasi dalam LPD maka pengelolaan LPD akan terlaksana secara efektif dan meningkatkan kepercayaan prinsipal sehingga pada akhirnya meningkatkan kinerja keuangan LPD. Berdasarkan uraian tersebut maka rumusan hipotesis kedua dalam penelitian ini adalah.

$\mathrm{H}_{2}$ : Prinsip accountability berpengaruh positif pada kinerja keuangan LPD di Kabupaten Klungkung. 
Responsibility adalah kesesuaian dan sikap perusahaan dalam mengelola usahanya berdasarkan peraturan undang - undang yang berlaku. Dalam upaya meningkatkan kinerjanya, perusahaan harus memahami dan mematuhi peraturan serta melaksanakan tanggung jawab terhadap masyarakat dan lingkungan sehingga dapat terpelihara kesinambungan usaha dalam jangka panjang dan mendapat pengakuan sebagai good corporate citizen (Putri dan Ulupui, 2017:39). Penelitian yang dilakukan oleh Hindistari dan Putri (2016) mendapatkan hasil bahwa prinsip responsibility memiliki pengaruh positif pada kinerja Bank Perkreditan Rakyat (BPR) di Kabupaten Gianyar. Begitupula dengan penelitian yang dilakukan oleh Sandraningsih dan Putri (2015) yang mendapatkan hasil yaitu prinsip responsibility memiliki pengaruh positif terhadap kinerja keuangan LPD di Kecamatan Abiansemal Kabupaten Badung. LPD yang taat dan patuh pada peraturan perundang - undangan yang berlaku serta melaksanakan tanggung jawabnya berdasarkan peraturan perundang - undangan maka dapat memberi dampak terhadap peningkatan kinerja keuangan LPD tersebut.

Sesuai dengan agency theory, hal ini menunjukkan bahwa dengan mematuhi segala peraturan yang ada serta melaksanakan tanggung jawab terhadap prinsipal dapat memberi dampak pada pertumbuhan LPD yang berdampak pada meningkatnya kinerja keuangan LPD. Berdasarkan uraian tersebut maka rumusan hipotesis ketiga dalam penselitian ini adalah:

$\mathrm{H}_{3}$ : Prinsip responsibility berpengaruh positif pada kinerja keuangan LPD di Kabupaten Klungkung.

Independency adalah suatu sikap perusahaan pada saat melakukan pengambilan keputusan tanpa terikat dengan pihak manapun atau pihak yang 
Made Oka Candra Andreana dan I Gde Ary Wirajaya.Pengaruh...

mendominasi. Perusahaan harus memiliki sikap objektif atau bebas dari kepentingan pihak yang dapat merugikan perusahaan. Untuk melancarkan pelaksanaan asas GCG, perusahaan harus dikelola secara independen sehingga masing - masing organ perusahaan tidak saling mendominasi dan tidak dapat diintervensi oleh pihak lain (Putri dan Ulupui, 2017:41).

Penelitian yang dilakukan oleh Bulandari dan Damayanthi (2014) mendapatkan hasil bahwa prinsip independency memiliki pengaruh positif terhadap kinerja keuangan LPD Kabupaten Badung. Hal serupa juga ditemukan dalam penelitian yang dilakukan oleh Sandraningsih dan Putri (2015) yang mendapatkan hasil bahwa prinsip independency memiliki pengaruh positif terhadap kinerja keuangan LPD di Kecamatan Abiansemal Kabupaten Badung. Pengelolaan LPD yang dikelola tanpa memiliki benturan kepentingan dari pihak lain yang dapat merugikan LPD serta dikelola secara objektif dapat memberi dampak terhadap peningkatan kinerja keuangan LPD tersebut.

Sesuai dengan agency theory, hal ini menunjukkan dengan tidak adanya benturan kepentingan dalam pengelolaan LPD dapat berdampak pada meningkatnya kepercayaan prinsipal serta kinerja keuangan LPD dan memastikan bahwa LPD telah bersikap objektif dalam pengelolaannya. Berdasarkan uraian tersebut maka rumusan hipotesis keempat dalam penelitian ini adalah:

$\mathrm{H}_{4}$ : Prinsip indepedency berpengaruh positif pada kinerja keuangan LPD di Kabupaten Klungkung.

Fairness adalah keadilan dan kesetaraan oleh pihak perusahaan dalam memenuhi kepentingan dari stakeholders yang ada berdasarkan perjanjian dan peraturan perundang - undangan yang berlaku. Prinsip ini menjadi faktor 
pendorong yang dapat mengendalikan dan memberi jaminan perlakuan yang adil dalam beragam kepentingan di perusahaan. Dalam melaksanakan kegiatannya, perusahaan harus senantiasa memperhatikan kepentingan pemegang saham dan pemangku kepentingan lainnya berdasarkan asas kewajaran dan kesetaraan (Putri dan Ulupui, 2017).

Berdasarkan penelitian yang dilakukan oleh Dewi dan Putri (2014) menyatakan bahwa prinsip fairness memiliki pengaruh positif terhadap kinerja keuangan LPD di Kabupaten Gianyar. Hal tersebut sejalan dengan penelitian yang dilakukan oleh Hindistari dan Putri (2016) yang mendapatkan hasil bahwa prinsip fairness berpengaruh positif pada kinerja Bank Perkreditan Rakyat Kabupaten Gianyar. LPD semestinya wajib memperhatikan hak dari pemangku kepentingan berdasarkan asas kewajaran dan kesetaraan tanpa adanya perlakuan yang tidak adil pada LPD tersebut, yang nantinya dapat memberi dampak kepada peningkatan kinerja keuangan LPD.

Sesuai dengan agency theory, hal ini menunjukkan apabila pengelola LPD memperhatikan hak dari prinsipal serta memperlakukannya secara adil berdasarkan asas kewajaran dan kesetaraan maka dapat meningkatkan kinerja keuangan LPD. Berdasarkan uraian tersebut maka rumusan hipotesis kelima dalam penelitian ini adalah:

$\mathrm{H}_{5}$ : Prinsip fairness berpengaruh positif pada kinerja keuangan LPD di Kabupaten Klungkung.

\section{METODE PENELITIAN}

Terdapat masalah yang terkait dengan kinerja keuangan LPD dan inkonsistensi dari hasil penelitian yang terkait dengan kinerja keuangan menjadi dasar 
dilakukannya penelitian ini. Lokasi dari penelitian ini adalah LPD yang berada di Kabupaten Klungkung dengan memberikan kuesioner dan mencari laporan keuangan dari tahun 2013 - 2016 pada LPD yang dijadikan sampel penelitian. Objek dari penelitian ini adalah prinsip - prinsip Good Corporate Governance yang terdiri dari transparancy, accountability, responsibility, indepedency dan fairness serta ROA untuk mengukur rasio kinerja keuangan LPD di Kabupaten Klungkung.

Seluruh LPD yang berada di Kabupaten Klungkung menjadi populasi dalam penelitian ini. LPD yang berada di Kabupaten Klungkung berjumlah 107 LPD yang berada di 4 Kecamatan. Jumlah masing - masing LPD pada tiap kecamatan yaitu Kecamatan Klungkung 22 buah LPD, Kecamatan Nusa Penida 35 buah LPD, Kecamatan Dawan 20 LPD dan Kecamatan Banjarangkan 30 LPD.

Penelitian ini menggunakan metode purposive sampling sebagai metode pengambilan sampel. Kriteria yang digunakan untuk penentuan sampel antara lain: 1) LPD yang berada di wilayah Kabupaten Klungkung daratan; 2) LPD yang tergolong sehat. Penarikan sampel dilakukan di wilayah Kabupaten Klungkung daratan karena adanya keterbatasan penelitian yang disebabkan karena tidak diperolehnya data keuangan LPD di kecamatan Nusa Penida serta faktor - faktor lain yaitu jarak dan kurangnya informasi tentang lokasi LPD yang ada di Kecamatan Nusa Penida. Penarikan sampel LPD yang tergolong sehat agar data keuangan yang akan digunakan dalam penelitian dijamin tersedia datanya. Rincian penentuan jumlah sampel dapat dijelaskan pada Tabel 1 sebagai berikut. 
Tabel 1.

Rincian Perhitungan Penentuan Jumlah Sampel Penelitian

\begin{tabular}{lc}
\hline \multicolumn{1}{c}{ Keterangan } & Jumlah \\
\hline Jumlah LPD yang tergolong aktif & 107 LPD \\
Kriteria : & \\
1) LPD di wilayah kecamatan Nusa Penida & 28 LPD \\
2) LPD cukup, kurang, dan tidak sehat & $\underline{24 \text { LPD }}$ \\
Jumlah Sampel Penelitian & 55 LPD \\
\hline
\end{tabular}

Sumber: Data diolah, 2018

Pada penelitian ini yang digunakan sebagai responden adalah orang - orang yang mengetahui wewenang dan tugas pengelolaan LPD dan fungsi - fungsi badan pengawas dalam menilai peranan Good Corporate Governance selama empat tahun terhadap kinerja keuangan LPD sepanjang tahun 2013-2016. Berdasarkan hasil perhitungan penentuan sampel diambil sampel berjumlah 55 LPD di Kabupaten Klungkung. Setiap LPD diambil dua orang responden yaitu kepala LPD dan badan pengawas LPD jadi total responden penelitian berjumlah 110 orang. Kepala LPD digunakan sebagai responden karena memiliki peran dalam operasional dan mengetahui seluruh kegiatan operasional di LPD sekaligus memiliki tanggung jawab terhadap kinerja LPD. Badan pengawas LPD dipilih sebagai responden karena memiliki peran dalam mengawasi kegiatan operasional LPD dan memiliki tanggung jawab pada laporan hasil pada paruman desa.

Pengumpulan data dalam penelitian ini adalah dengan metode survei yaitu menggunakan teknik kuesioner dan dokumentasi. Jenis data menurut sifatnya yang digunakan dalam penelitian ini adalah data kuantitatif. Data kuantitatif pada penelitian ini ialah angka dalam laporan keuangan LPD di Kabupaten Klungkung dan data skor jawaban kuesioner yang terkumpul dari responden. Jenis data menurut sumbernya yang digunakan dalam penelitian ini adalah sebagai berikut.

1) Penelitian menggunakan data primer berupa skor jawaban kuesioner oleh 
responden penelitian. 2) Penelitian menggunakan data sekunder berupa data yang diperoleh dari laporan keuangan masing - masing LPD di Kabupaten Klungkung tahun 2013-2016. Teknik analisis data yang digunakan dalam penelitian ini adalah analisis regresi linear berganda.

\section{HASIL DAN PEMBAHASAN}

Peneliti menyebarkan kuesioner kepada LPD yang berada di Kabupaten Klungkung berjumlah 110 kuesioner dan yang kembali sebanyak 110 kuesioner. Rincian data pengambilan instrument dapat dilihat pada Tabel 2.

Tabel 2.

Data Pengiriman dan Pengembalian Kuisioner

\begin{tabular}{lc}
\hline \multicolumn{1}{c}{ Keterangan } & Jumlah \\
\hline Kuesioner yang disebarkan & 110 \\
Kuesioner yang tidak kembali & 0 \\
Kuesioner yang dikembalikan dan digunakan & 110 \\
Tingkat pengembalian yang digunakan & \\
(usability response rate) & $110 / 110 \times 100 \%=100 \%$ \\
\hline Sumber: Data diolah 2018 &
\end{tabular}
Sumber: Data diolah, 2018

Berdasarkan tingkat pendidikan karakteristik responden menunjukkan responden sejumlah 110 orang terdiri atas beberapa jenjang pendidikan antara lain sebanyak 65 orang $(59 \%)$ memiliki pendidikan terakhir SMA, sebanyak 7 orang (6\%) pendidikan D3, dan sebanyak 38 orang (35\%) pendidikan terakhir pada jenjang $S 1$.

Pengujian instrument penelitian ini meliputi uji validitas dan uji reliabilitas. Uji validitas digunakan untuk menguji apakah instrument penelitian dapat dikatakan valid apabila mampu mengukur apa yang diinginkan dalam mengungkapkan data dari variabel yang diteliti secara tepat. Hasil uji validitas dalam penelitian ini disajikan dalam Tabel 3 sebagai berikut. 
Tabel 3.

Hasil Uji Validitas

\begin{tabular}{lccc}
\hline Variabel & Indikator & $\begin{array}{c}\text { Koefisien } \\
\text { Korelasi }\end{array}$ & $\begin{array}{c}\text { Nilai } \\
\text { Signifikansi }\end{array}$ \\
\hline Transparancy & $\mathrm{X} 1.1$ & 0,798 & 0,000 \\
& $\mathrm{X} 1.2$ & 0,860 & 0,000 \\
& $\mathrm{X} 1.3$ & 0,860 & 0,000 \\
Accountability & $\mathrm{X} 1.4$ & 0,847 & 0,000 \\
& $\mathrm{X} 2.1$ & 0,899 & 0,000 \\
& $\mathrm{X} 2.2$ & 0,879 & 0,000 \\
& $\mathrm{X} 2.3$ & 0,890 & 0,000 \\
Responsibility & $\mathrm{X} 2.4$ & 0,833 & 0,000 \\
& $\mathrm{X} 3.1$ & 0,904 & 0,000 \\
& $\mathrm{X} 3.2$ & 0,885 & 0,000 \\
Independency & $\mathrm{X} 3.3$ & 0,827 & 0,000 \\
& $\mathrm{X} 3.4$ & 0,832 & 0,000 \\
& $\mathrm{X} 4.1$ & 0,746 & 0,000 \\
Fairness & $\mathrm{X} 4.2$ & 0,865 & 0,000 \\
& $\mathrm{X} 4.3$ & 0,917 & 0,000 \\
& $\mathrm{X} 5.1$ & 0,871 & 0,000 \\
& $\mathrm{X} 5.2$ & 0,827 & 0,000 \\
& $\mathrm{X} 5.3$ & 0,912 & 0,000 \\
& $\mathrm{X} 5.4$ & 0,885 & 0,000 \\
\hline
\end{tabular}

Sumber: Data diolah, 2018

Hasil pengujian validitas memperoleh nilai koefisien korelasi (r) pada seluruh indikator pada variabel lebih besar dari 0,3 dengan tingkat signifikansi lebih kecil dari 0,05 maka dapat dikatakan instrument dalam penelitian ini adalah valid.

Pengujian reliabilitas atau keandalan instrumen menunjukkan sejauh mana suatu pengukuran kembali terhadap gejala yang sama. Hasil uji reliabilitas dalam penelitian ini disajikan dalam Tabel 4 sebagai berikut.

Tabel 4.

Uji Reliabilitas

\begin{tabular}{lc}
\hline \multicolumn{1}{c}{ Variabel } & Cronbach's Alpha \\
\hline Transparancy & 0,861 \\
Accountability & 0,898 \\
Responsibility & 0,872 \\
Independency & 0,800 \\
Fairness & 0,894 \\
\hline Sumber: Data diolah, 2018
\end{tabular}

Sumber: Data diolah, 2018 
Hasil uji yang disampaikan pada Tabel 4 menunjukkan seluruh nilai koefisien Cronbach's Alpha dari instrumen memiliki koefisien Cronbach's Alpha > 0,6 sehingga instrumen penelitian ini dapat dikatakan reliabel, hal ini bermakna bahwa pengukuran tersebut dapat memberikan hasil yang konsisten ketika dilakukan pengukuran kembali pada subjek yang sama di waktu yang berbeda.

Pengujian asumsi klasik bertujuan untuk mengetahui hubungan antarvariabel bebas dariu segala jenis gejala asumsi klasik sehingga dapat mengintrepetasikan data dengan lebih akurat. Uji Kolmogorov-Smirnov dipergunakan sebagai uji normalitas data dalam penelitian ini. Residual yang memiliki distribusi normal yaitu ketika nilai Asymp. Sig (2-Tailed) dari uji normalitas nilainya lebih besar dari taraf signifikansi $\alpha=0,05$. Pengujian asumsi klasik yakni uji normalitas dilakukan untuk menguji apakah data berdistribusi normal atau tidak. Hasil uji normalitas data penelitian dapat dilihat pada Tabel 5 berikut.

Tabel 5.

Hasil Uji Normalitas

\begin{tabular}{lc}
\hline & Unstandardized Residual \\
\hline $\mathrm{N}$ & 110 \\
Kolmogorov Smirnov Z & 0,671 \\
Asymp.Sig (2-tailed) & 0,759 \\
\hline Sumber: Data diolah, 2018
\end{tabular}

Sumber: Data diolah, 2018

Hasil uji pada Tabel 5 menunjukan bahwa nilai Astmp.Sig (2-tailed) dari uji normalitas adalah sebesar 0,759 atau lebih besar dari $\alpha=0,05$. Hal ini menunjukan bahwa model dalam penelitian ini berdistribusi normal.

Bebas dari gejala multikoloniear merupakan syarat dari model regresi dapat dikatan baik. Pendeteksian terhadap ada atau tidaknya hubungan 
antarvariabel independen terlihat dari nilai tolerance atau nilai VIF. Menunjukkan ada tidaknya gejala multikolinieritas diperlukan nilai cut off yang umum digunakan yaitu nilai tolerance $>0,10$ atau nilai VIF $<10$. Hasil uji multikolieritas data penelitian dapat dilihat pada Tabel 6 berikut.

Tabel 6.

Hasil Uji Multikolinearitas

\begin{tabular}{lcc}
\hline \multicolumn{1}{c}{ Variabel } & Tolerance & VIF \\
\hline Transparancy & 0,359 & 2,782 \\
Accountability & 0,234 & 4,272 \\
Responsibility & 0,340 & 2,942 \\
Independency & 0,446 & 2,243 \\
Fairness & 0,301 & 3,328 \\
\hline
\end{tabular}

Sumber: Data diolah, 2018

Berdasarkan hasil uji multikolinearitas pada Tabel 6, dapat diketahui bahwa tidak ada variabel independen yang memiliki nilai tolerance $\leq 0,10$ dan nilai VIF $\geq 10$. Analisis ini menunjukkan bahwa tidak terdapat gejala multikolinearitas terhadap variabel penelitian.

Nilai absolute residual diregresikan terhadap variabel independennya merupakan cara yang dilakukan untuk melakukan pengujian heteroskedastisitas. Tidak terdapat gejala heteroskedastisitas pada data penelitian apabila nilai signifikansi absolute residual terhadap variabel independennya lebih besar dari taraf signifikansi $\alpha=0,05$. Hasil uji heteroskedastisitas data penelitian dapat dilihat pada Tabel 7.

Tabel 7. Hasil Uji Heteroskedastisitas

\begin{tabular}{lc}
\hline \multicolumn{1}{c}{ Variabel } & Sig \\
\hline Transparancy & 0,597 \\
Accountability & 0,736 \\
Responsibility & 0,557 \\
Independency & 0,682 \\
Fairness & 0,406 \\
\hline
\end{tabular}

Sumber: Data diolah, 2018 
Made Oka Candra Andreana dan I Gde Ary Wirajaya.Pengaruh...

Pengujian kelayakan model (uji F) terlihat dari signifikasi yang ditunjukkan pada tabel anova dengan membandingkan tingkat signifikasi variabel bebas dengan signifikansi $\alpha=0,05$. Hasil pengujian $\mathrm{F}$ memperoleh hasil bahwa nilai F 53,016 dan tingkat signifikansi 0,000. Tingkat signifikansi $0,000<0,05$ maka model regresi dapat dipergunakan memprediksi variabel independenden hal ini bermakna bahwa prinsip transparancy, accountability, responsibility, indepedency dan fairness secara bersama-sama berpengaruh terhadap kinerja keuangan.

Kemampuan model dalam menerangkan variasi variabel terikat diukur dengan koefisien determinasi. Koefisien adjusted $\mathrm{R}^{2}$ pada penelitian ini 0,705 . Ini menyatakan bahwa 70,5\% keragaman faktor yang memengaruhi kinerja keuangan antara lain variabel independen yaitu transparancy, accountability, responsibility, indepedency dan fairness. Namun sisanya 29,5\% (100\% - 70,5\%) dapat dijelaskan oleh faktor lain diluar model penelitian ini.

Uji t digunakan agar mengetahui pengaruh variabel bebas pada variabel terikat secara parsial. Dari hasil pengujian ditunjukkan pada Tabel 8.

Tabel 8.

Hasil Uji t

\begin{tabular}{lccccc}
\hline \multirow{2}{*}{ Model } & \multicolumn{2}{c}{$\begin{array}{c}\text { Unstandardized } \\
\text { Coefficients }\end{array}$} & $\begin{array}{c}\text { Standardized } \\
\text { Coeficient }\end{array}$ & T & \multirow{2}{*}{ Sig. } \\
\cline { 2 - 4 } & \multicolumn{2}{c}{ B } & Std. Error & Beta & \\
\hline (Constant) & $-0,0024$ & 0,003 & & $-0,708$ & 0,481 \\
X1 & 0,0008 & 0,000 & 0,191 & 2,202 & 0,030 \\
X2 & 0,0009 & 0,000 & 0,226 & 2,101 & 0,038 \\
X3 & 0,0008 & 0,000 & 0,183 & 2,054 & 0,042 \\
X4 & 0,0010 & 0,000 & 0,173 & 2,218 & 0,029 \\
X5 & 0,0008 & 0,000 & 0,187 & 1,971 & 0,050 \\
\hline
\end{tabular}

Sumber: Data diolah, 2018

Hasil uji t menunjukkan variabel transparancy nilai t hitungnya 2,202 dan signifikansi 0,03 ini bermakna bahwa prinsip transparancy memiliki pengaruh 
yang positif pada kinerja LPD di Kabupaten Klungkung. Untuk variabel accountability nilai t hitungnya sebesar 2,101 signifikansi 0,04 hal ini berarti bahwa prinsip accountability memiliki pengaruh yang positif pada kinerja LPD di Kabupaten Klungkung. Variabel responsibility memiliki nilai t hitung sebesar 2,054 dan signifikansi 0,04 yang memiliki nilai kurang dari 0,05 ini memiliki arti bahwa prinsip responsibility memiliki pengaruh positif pada kinerja LPD di Kabupaten Klungkung. Variabel independency sebesar 2,218 dengan tingkat signifikansi 0,03 ini memiliki arti bahwa prinsip independency berpengaruh positif pada kinerja LPD di Kabupaten Klungkung. Variabel fairness nilai t hitungnya sebesar 1,971 signifikansi 0,05 hal ini memiliki berarti bahwa prinsip fairness berpengaruh positif pada kinerja LPD di Kabupaten Klungkung.

Hasil uji regresi ditunjukkan pada Tabel 8 memperoleh model regresi dalam penelitian ini sebagai berikut.

$$
Y=-0,0024+0,0008 X 1+0,0009 X 2+0,0008 X 3+0,0010 X 4+0,0008 X 5
$$

Berdasarkan model persamaan regresi tersebut dapat dijelaskan informasi yaitu nilai koefisien transparancy $\left(\mathrm{X}_{1}\right)$ yaitu 0,0008 berarti apabila variabel transparancy mengalami peningkatan dalam penerapannya, maka kinerja keuangan akan meningkat. Nilai koefisien accountability $\left(\mathrm{X}_{2}\right)$ yaitu 0,0009 memiliki arti apabila variabel accountability mengalami peningkatan ketika penerapannya, maka kinerja keuangan akan meningkat pula. Nilai koefisien responsibility $\left(\mathrm{X}_{3}\right)$ 0,0008 memiliki arti bahwa apabila variabel responsibility ditingkatkan penerapannya, maka kinerja keuangan mengalami peningkatan juga dengan asumsi variabel bebas lainnya adalah konstan. 
Nilai koefisien indepedency $\left(\mathrm{X}_{4}\right)$ sebesar 0,0010 memiliki arti bahwa apabila variabel indepedency meningkat ketika diterapkan, maka kinerja keuangan akan dapat mengalami peningkatan pula. Koefisien fairness $\left(\mathrm{X}_{5}\right)$ 0,0008 memberikan arti bahwa ketika variabel fairness penerapannya ditingkatkan di LPD, maka kinerja keuangan mengalami peningkatan pula dengan asumsi variabel bebas lainnya tidak terdapat perubahan.

Berdasarkan olahan SPSS yang termuat dalam Tabel 8, hasilnya menunjukkan bahwa variabel transparancy memiliki pengaruh yang positif pada kinerja keuangan LPD di Klungkung. Dapat dilihat dari nilai signifikansi 0,030 dimana nilai tersebut kurang dari tingkat signifikan yang ditetapkan $(\alpha=0,05)$ jadi hipotesis pertama $\left(\mathrm{H}_{1}\right)$ diterima yakni prinsip transparancy memiliki pengaruh yang positif pada kinerja keuangan LPD di Klungkung.

Hasil dari penelitian ini memperkuat penelitian Setyawan dan Putri (2013), Dewi dan Putri (2014), Bulandari dan Damayanthi (2014), dan Hindistari dan Putri (2016) yang menyatakan bahwa prinsip transparancy berpengaruh terhadap kinerja keuangan LPD. Sesuai dengan agency theory, hal ini menunjukkan bahwa semakin transparan LPD dalam mengungkapkan informasi mengenai keadaan LPD menyebabkan peningkatan kepercayaan prinsipal, maka kinerja keuangan LPD tersebut akan meningkat pula.

Berdasarkan hasil olahan SPSS yang termuat dalam Tabel 8, hasilnya menunjukkan bahwa variabel accountability memiliki pengaruh yang positif pada kinerja keuangan LPD di Klungkung. Ditunjukkan dari nilai signifikansi yaitu 0,038 yang nilainya kurang dari tingkat signifikan $\alpha=0,05$ sehingga hipotesis 
kedua $\left(\mathrm{H}_{2}\right)$ diterima yakni prinsip accountability berpengaruh positif pada kinerja keuangan LPD di Klungkung.

Penelitian ini memperoleh hasil yang mendukung penelitian Bulandari dan Damayanthi (2014), Dewi dan Putri (2014), Sandraningsih dan Putri (2015), dan Hindistari dan Putri (2016) yang menyatakan bahwa prinsip accountability berpengaruh terhadap kinerja keuangan LPD. Sesuai dengan agency theory, hal ini menunjukkan bahwa semakin jelas wewenang dan fungsi pelaksanaan serta pertanggungjawaban struktur organisasi dalam LPD maka pengelolaan LPD akan terlaksana secara efektif dan meningkatkan kepercayaan prinsipal sehingga pada akhirnya meningkatkan kinerja keuangan LPD.

Berdasarkan hasil olahan SPSS yang termuat dalam Tabel 8, hasilnya menunjukkan bahwa variabel responsibility memiliki pengaruh positif pada kinerja keuangan LPD Klungkung. Nilai signifikansi sebesar 0,042 nilainya lebih kecil dari tingkat signifikan 0,05 sehingga hipotesis ketiga $\left(\mathrm{H}_{3}\right)$ diterima yakni prinsip responsibility berpengaruh positif pada kinerja keuangan LPD di Klungkung.

Penelitian ini memperkuat penelitian Setyawan dan Putri (2013), Bulandari dan Damayanthi (2014), Sandraningsih dan Putri (2015), dan Hindistari dan Putri (2016) yang menyatakan bahwa prinsip responsibility berpengaruh terhadap kinerja keuangan LPD. Sesuai dengan agency theory, hal ini menunjukkan bahwa dengan mematuhi segala peraturan yang ada serta melaksanakan tanggung jawab terhadap prinsipal dapat memberi dampak pada pertumbuhan LPD yang berdampak pada meningkatnya kinerja keuangan LPD. 
Berdasarkan hasil olahan SPSS yang termuat dalam Tabel 8, hasilnya menunjukkan bahwa variabel independency memiliki pengaruh yang positif pada kinerja keuangan LPD di Klungkung. Ditunjukkan dari nilai signifikansi sebesar 0,029 yang nilainya lebih kecil dari tingkat signifikan yang ditetapkan $(\alpha=0,05)$ sehingga hipotesis keempat $\left(\mathrm{H}_{4}\right)$ diterima yakni prinsip independency berpengaruh positif pada kinerja keuangan LPD di Kabupaten Klungkung.

Hasil penelitian ini mendukung hasil penelitian yang dilakukan oleh Setyawan dan Putri (2013), Bulandari dan Damayanthi (2014), Sandraningsih dan Putri (2015), dan Hindistari dan Putri (2016) yang menyatakan bahwa prinsip independency berpengaruh terhadap kinerja keuangan LPD. Sesuai dengan agency theory, hal ini menunjukkan dengan tidak adanya benturan kepentingan dalam pengelolaan LPD dapat berdampak pada meningkatnya kepercayaan prinsipal serta kinerja keuangan LPD dan memastikan bahwa LPD telah bersikap objektif dalam pengelolaannya.

Berdasarkan hasil olahan SPSS yang termuat dalam Tabel 8, hasilnya menunjukkan bahwa variabel fairness mmeberikan pengaruh yang positif terhadap kinerja keuangan LPD di Kabupaten Klungkung. Nilaia signifikansi sebesar 0,050 menunjukkan nilainya sama dengan tingkat signifikan $\alpha=0,05$ maka hipotesis kelima $\left(\mathrm{H}_{5}\right)$ diterima yakni prinsip fairness berpengaruh positif pada kinerja keuangan LPD di Klungkung.

Penelitian ini memberikan dukungan pada penelitian Dewi dan Putri (2014), Bulandari dan Damayanthi (2014), Sandraningsih dan Putri (2015), dan Hindistari dan Putri (2016) yang menyatakan bahwa prinsip fairness berpengaruh 
terhadap kinerja keuangan LPD. Sesuai dengan agency theory, hal ini menunjukkan apabila pengelola LPD memperhatikan hak dari prinsipal serta memperlakukannya secara adil berdasarkan asas kewajaran dan kesetaraan maka dapat meningkatkan kinerja keuangan LPD.

Hasil penelitian ini memberikan tambahan informasi mengenai bagaimana prinsip transparancy, accountability, responsibility, independency, dan fairness mempengaruhi kinerja keuangan LPD yang ada di Kabupaten Klungkung. Terdapat bukti empiris yang diperoleh melalui penelitian ini yaitu prinsip transparancy, accountability, independency, responsibility, dan fairness memiliki pengaruh yang positif terhadap kinerja keuangan LPD yang ada di Klungkung. Hal ini berarti semakin meningkatnya penerapan prinsip transparancy, accountability, responsibility, independency, dan fairness dalam sebuah LPD akan semakin meningkat pula kinerja keuangan LPD tersebut.

Hasil penelitian ini dapat menjadi pertimbangan bagi pengelola LPD untuk mempertimbangkan penerapan prinsip - prinsip GCG yaitu transparancy, accountability, responsibility, independency, dan fairness ketika mengelola LPD. Hal ini dapat dilakukan melalui publikasi laporan keuangan secara transparan, memberi kejelasan struktur dan wewenang dalam pengeloaan LPD, mentaati undang - undang yang berlaku, pengambilan keputusan dalam LPD tidak dipengaruhi pihak lain serta bersifat objektif, dan memperlakukan stakeholder secara adil. Dengan penerapan kelima prinsip tersebut dapat meningkatkan kepercayaan nasabah dan masyarakat desa adat yang nantinya berdampak pada peningkatan kinerja keuangan LPD. 
Made Oka Candra Andreana dan I Gde Ary Wirajaya.Pengaruh...

\section{SIMPULAN}

Pengujian dan pembahasan mengenai pengaruh variabel transparancy, accountability, responsibility, independency, dan fairness pada kinerja keuangan LPD di Klungkung, datap ditarik kesimpulan sebagai berikut. 1) Pengelolaan LPD yang transparan akan meningkatkan kinerja keuangan LPD. 2) Pengelolaan LPD dengan akuntabilitas yang baik akan meningkatkan kinerja keuangan LPD. 3) Pengelolaan LPD yang mematuhi peraturan serta perundang - undangan yang ada akan meningkatkan kinerja keuangan LPD. 4) Pengelolaan LPD yang independen tanpa campur tangan pihak lain dalam pengambilan keputusan LPD akan meningkatkan kinerja keuangan LPD. 5) Pengelolaan LPD yang memperlakukan stakeholder dengan adil dan setara akan membuat kinerja keuangan LPD mengalami peningkatan.

Hal ini dapat ditunjukkan dengan semakin baik penerapan variabel transparancy, accountability, responsibility, independency, dan fairness dalam pengelolaan sebuah LPD maka kinerja keuangan LPD juga akan mengalami peningkatan. Begitupula sebaliknya, jika semakin buruk penerapan variabel transparancy, accountability, responsibility, independency, dan fairness dalam pengelolaan sebuah LPD maka kinerja keuangan LPD juga akan mengalami penurunan. Berdasarkan atas hasil penelitian, beberapa saran dapat disampaikan antara lain 1) Pengujian terhadap pengaruh prinsip Transparancy, Accountability, Responsibility, Independency, dan Fairness terhadap kinerja keuangan LPD memberikan bukti bahwa variabel - variabel tersebut memiliki pengaruh yang positif terhadap kinerja keuangan suatu LPD. Diantara kelima variabel 
independen yang diuji, variabel independency memiliki pengaruh terbesar pada kinerja keuangan, oleh karena itu pengelola LPD disarankan untuk meningkatkan prinsip independency dalam pengelolaan LPD. 2) Keterbatasan penelitian hanya melihat dari aspek keuangan saja. Penelitian selanjutnya, disarankan untuk dapat menggunakan LPD di kabupaten yang berbeda agar penelitian mengenai hal serupa mengalami penyempurnaan serta tidak mengukur hanya pada aspek keuangan saja tetapi ju mengukur pada aspek non keuangan juga penting untuk diperhatikan dalam penelitian.

\section{REFERENSI}

Bulandari, I. G. A. W., dan Damayanthi, I. G. A. E. 2014. Pengaruh PrinsipPrinsip Good Corporate Governance Pada Kinerja Keuangan Lembaga Perkreditan Desa Di Kabupaten Badung. E-Jurnal Akuntansi Universitas Udayana, 8(3), 641-659.

Clemente, A. G., dan Labat, B. N. 2009. Disclosure . The Role Of Independent Directors In The. International Journal Of Accounting Information System, $5,1-50$.

Dewi, K. K., dan Putri, I. G. A. M. A. D. 2014. Pengaruh Penerapan PrinsipPrinsip Gcg Pada Kinerja Keuangan Lembaga Perkreditan Desa Kabupaten Gianyar, Provinsi Bali Fakultas Ekonomi Dan Bisnis Universitas Udayana, Ba. E-Jurnal Akuntansi Universitas, 8(1), 70-82.

Dewi, K. K., dan Putri, I. G. A. M. A. D. 2014. Pengaruh Penerapan PrinsipPrinsip Gcg Pada Kinerja Keuangan Lembaga Perkreditan Desa Kabupaten Gianyar Bali. E-Jurnal Akuntansi Universitas Udayana, 7(3), 559-573.

Eisenhardt, K. M. 1989. Agency Theory: An Assessment And Review Linked References Are Available On Jstor For This Article: Agency Theory: An Assessment And Review, 14(1), 57-74.

Hindistari, R. R., dan Putri, I. G. A. M. A. D. 2016. Pengaruh Penerapan PrinsipPrinsip Good Corporate Governance Pada Kinerja Bank Perkreditan Rakyat. E-Jurnal Akuntansi Universitas Udayana, 16(1), 101-128.

KNKG. 2006. Pedoman Umum Good Corporate Governance Indonesia. Jakarta 
Mahaendrayasa, P. K. A., dan Putri, I. G. A. M. A. D. 2017. Pengaruh Prinsip Prinsip Good Corporate Governance Terhadap Kinerja Keuangan Lembaga Perkreditan Desa Di Kota Denpasar. Universitas Udayana.

Putri, I. G. A. M. A. D., dan Ulupui, I. G. K. A. 2017. Pengantar Corporate Governance. Denpasar: CV. Sastra Utama.

Rambo, C. M. 2013. Influence Of The Capital Markets Authority's Corporate Governance Guidelines On Financial Performance Of Commercial Banks In Kenya Charles. The International Journal Of Business And Finance Research, 7(3), 77-92.

Sandraningsih, N. K. B., dan Putri, I. G. A. M. A. D. 2015. Pengaruh PrinsipPrinsip Good Corporate Governance Pada Kinerja Keuangan Lembaga Perkreditan Desa Kecamatan Abiansemal. E-Jurnal Akuntansi Universitas Udayana, 3(11), 878-893.

Sastra, I. M. B., dan Erawati, N. M. A. 2017. Pengaruh Penerapan Prinsip-Prinsip Good Corporate Governance Dan Budaya Tri Hita Karana Pada Kinerja Keuangan. E-Jurnal Akuntansi Universitas Udayana, 19(1), 421-451.

Setyawan, K. M., dan Putri, I. G. A. M. A. D. 2013. Pengaruh Good Corporate Governance Terhadap Kinerja Keuangan Lembaga Pekreditan Desa Di Kecamatan Mengwi Kabupaten Badung. E-Jurnal Akuntansi, 5(3), 586598.

Waddock, S. A., dan Graves, S. B. 1997. The Corporate Social Performance Financial Performance Link. Strategic Management Journal, 18(4), 303319.

Www.balisaja.Com/2015/10/Kasus-Kasus-Lpd-Di-Bali-Mesti-Ditangani.Html Diakses Pada Tanggal 26, Bulan Mei, Tahun 2017

Www.Indonesiasatu.Co/Detail/Ojk-Ingatkan-Lpd-Bali-Yang-Gagal-Bayar-UangNasabah Diakses Pada Tanggal 26, Bulan Mei, Tahun 2017

Www. Industri.Bisnis.Com/Read/20160613/87/557314/Bank-Indonesia-SarankanLpd-Di-Bali-Perkuat-Manajemen- Diakses Pada Tanggal 26, Bulan Mei, Tahun 2017

Www.Klungkungkab.Go.Id/Index.Php/Baca-Berita/6350/Lpd-MenerimaBantuan-Penyertaan-Modal Diakses Pada Tanggal 26, Bulan Mei, Tahun 2017 
ISSN: 2302-8556

E-Jurnal Akuntansi Universitas Udayana

Vol.23.2. Mei (2018): 1305-1331

Www.Posbali.Id/Tiga-Masalah-Hantui-Lpd/ Diakses Pada Tanggal 26, Bulan Mei, Tahun 2017 